\title{
Inequalities between peri-urban and urban areas in urbanization process of Ho Chi Minh City: An urban political-ecology perspective
}

\author{
Tran Tu Van Anh ${ }^{1 *}$, Nguyen Minh Doi ${ }^{1}$, Dao Vu Bich Diem ${ }^{1}$, Quan Minh Quoc Binh ${ }^{1}$, \\ Nguyen Ngoc Dan Thanh ${ }^{1}$, Nguyen Tran Cam Linh ${ }^{1}$, Doan Thi Thanh Thuy ${ }^{1}$ \\ ${ }^{1}$ Ho Chi Minh City Open University, Vietnam \\ *Corresponding author: anh.ttv@ou.edu.vn
}

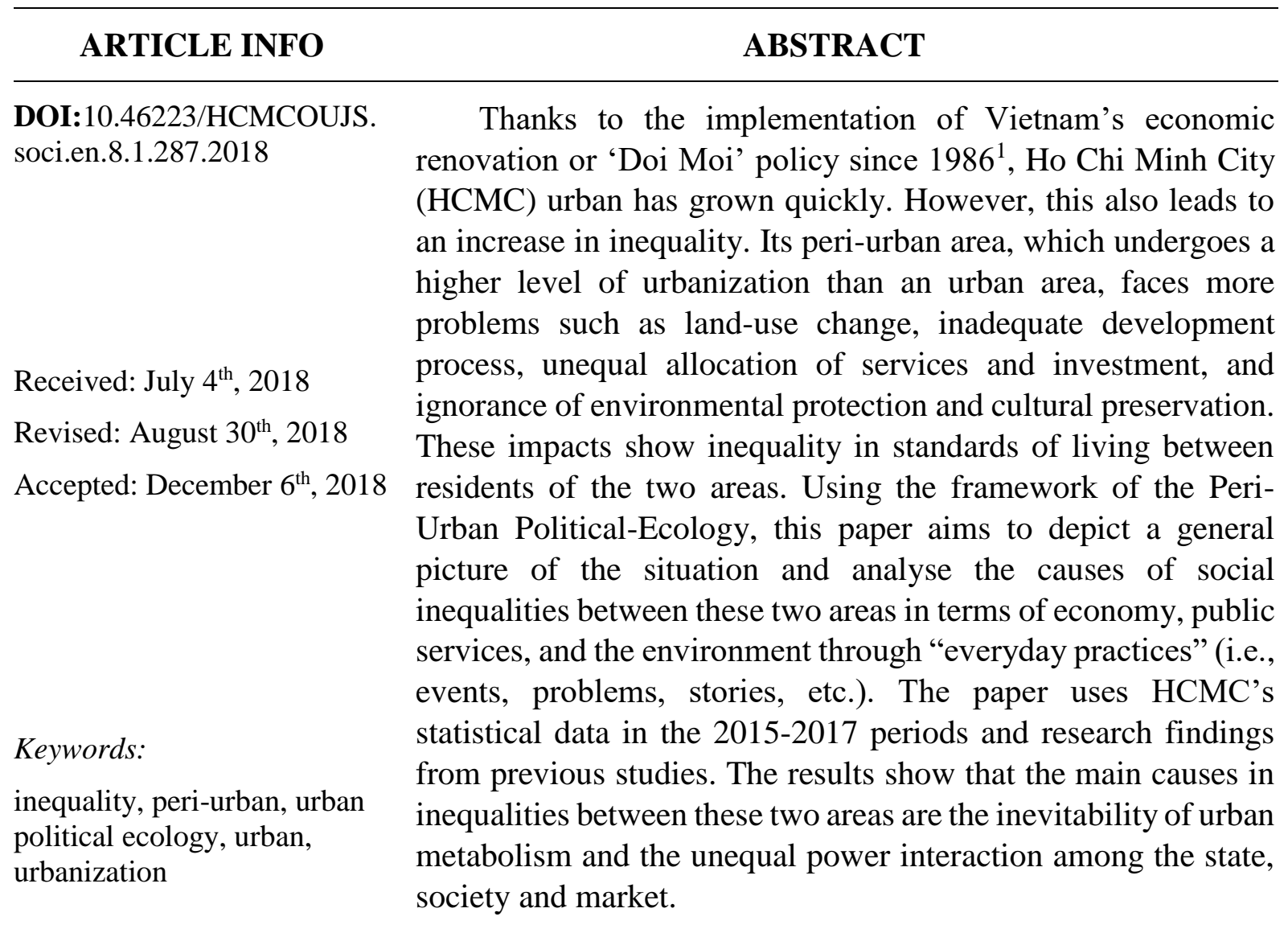

\section{Introduction}

Originated in 1995, the rapid and vigorous growth of urbanization of Ho Chi Minh City with a current rate of around $37 \%$ is driven by the fast-growing population, a shift from previous rural districts to new urban ones and a rapid increase in the number of industrial zones. The city's population has proportionally doubled from 4.6 million in 1995 to around 8.6 million in 2017 due to the great influx of immigrants. The number of export processing zones and

\footnotetext{
${ }^{1}$ With 'Doi Moi' policy, Vietnam has followed main elements: (1) Shifting from a planned centralized economy based on public ownership to a multi-sector economy based on the market and urbanization development; (2) Democratizing social life by building a state on the basis of the rule of law; (3) Strengthening external cooperation with other countries (United Nations, 2016)
} 
industrial parks also increased from 1 in 1991 to 15 in 2017 attracting from 80,000 to 100,000 migrant laborers every year from rural areas to the city working in export-oriented laborintensive industries (GSO, 2017).

The rapid urbanization process, on the one hand, helps to improve HCMC's economic growth and its people's living standards but, on the other, also results in inequalities in economy, public services and environment between its suburban and urban areas. Compared to its urban area, the peri-urban area of HCMC undergoes a higher level of urbanization, and thus, faces a conflict between lower infrastructure expansion and faster-growing population (Truong, 2013). The next section of the study shows how factors such as land-use change, inadequate development, unequal distribution of services and investment, and ignorance of environmental protection and cultural preservation in the peri-urban areas lead to problems in income, land possession, land speculation, education opportunities, healthcare and environment protection. Although urbanization in HCMC leads to various problems about social inequalities, there has been little research on the in-depth relationship between development, urbanization and inequality, especially between the city's peri-urban and urban areas. Employed the framework of the Peri-Urban Political Ecology, this paper attempts to depict an overview and analyse the causes of the social inequalities between the urban and the peri-urban in economic, public services, and environmental aspects.

Administratively, Ho Chi Minh City has 24 districts divided into three groups (1) 13 urban districts $(1,3,4,5,6,8,10,11$, Phu Nhuan, Binh Thanh, Go Vap, Tan Binh, and Tan Phu), (2) 6 peri-urban districts (2, 7, 9, 12, Binh Tan, and Thu Duc) and (3) 5 rural districts (Cu Chi, Binh Chanh, Hoc Mon, Nha Be, Can Gio) (GSO, 2015). For the purposes of this report, this administrative map is classified into 3 areas as urban, peri-urban and rural based on their status of urbanization. The peri-urban area in this report has 10 districts comprising 2, 7, 9, 12, Binh Tan, and Thu Duc, Cu Chi, Binh Chanh, Hoc Mon, Nha Be and 13 urban districts as stated in the official administrative map ${ }^{2}$. Based on the city's statistic figures for the 2015-2017 periods, this paper aims at analyzing existing data on economic, social and environmental issues at city level and data collected from previous research about urbanization and inequality in Ho Chi Minh City as the second source. The analysis aims to answer the two following research questions:

1) What are the status and causes of inequalities between HCMC's peri-urban and urban areas?

2) What should be done to minimize these inequalities?

Accordingly, the report is organized in three sections. The first is the introduction section. The second is the theoretical literature of the concept of Peri-Urban Political Ecology. The last section will picture inequalities between HCMC's peri-urban and urban areas about the economy, public services and quality of natural and social environments. The paper then tries to draw a conclusion based on the analyzed data using the Peri-Urban Political Ecology

${ }^{2} \mathrm{Cu}$ Chi, Binh Chanh, Hoc Mon, Nha Be districts are classified as the peri-urban areas due to agricultural land use decrease and urban land use increase recently 
framework to explain the causes. Finally, the report will make some recommendations for policymakers to reduce these inequalities.

\section{Theoretical framework for analysing inequalities between urban and peri-urban} areas

Political ecology is an inter-disciplinary and trans-disciplinary field potential to "foster an understanding of the urban that is not limited to the city" (Swyngedouw \& Heynen, 2003). Since its first formation and application by Blaikie and Brookfield into urban context in 1987, the concept of Urban Political Ecology (UPE) has evolved in many different directions (Zimmer, 2010). Based on two main branches of political ecology in urban studies including Marxist and Post-Colonial views, this paper looks at these views not only in the urban but also in the peri-urban area.

The Marxist UPE perspective points out a giant socio-environmental process in capitalism through a political approach that forms an urban political ecology. Therefore, the study focus should be on analysing inequalities through investigating power relations among stakeholders of cities in terms of economic, historical and political aspects. This view implies that the cause of inequalities between urban and peri-urban can be found by answering the two questions: (a) Who has the power to make decisions about the peri-urban environment? and (b) Who benefits, who loses, who wins in the peri-urban environmental decision-making process?

Post-colonial UPE is less concerned with the urban as a global process but more interested in studying cities as daily life sites. By this way, this view also helps to understand the relations in the peri-urban "including how relations are formed and stabilized, how the city is made to work to secure livelihoods and identities and how people scale themselves through their networks to access resources and opportunities" (Simone, 2004).

The two above approaches provide a strong framework for analysing inequalities between urban and peri-urban areas. Accordingly, the status of inequalities between these two areas can be observed and analysed through "everyday practices" such as events, problems, stories, and so on, in economics, public services, and the environment. Besides, the power relations among the state, market and civil society who play a role in the interaction between society and economy with nature can also be employed to explain inequalities between the urban and the peri-urban.

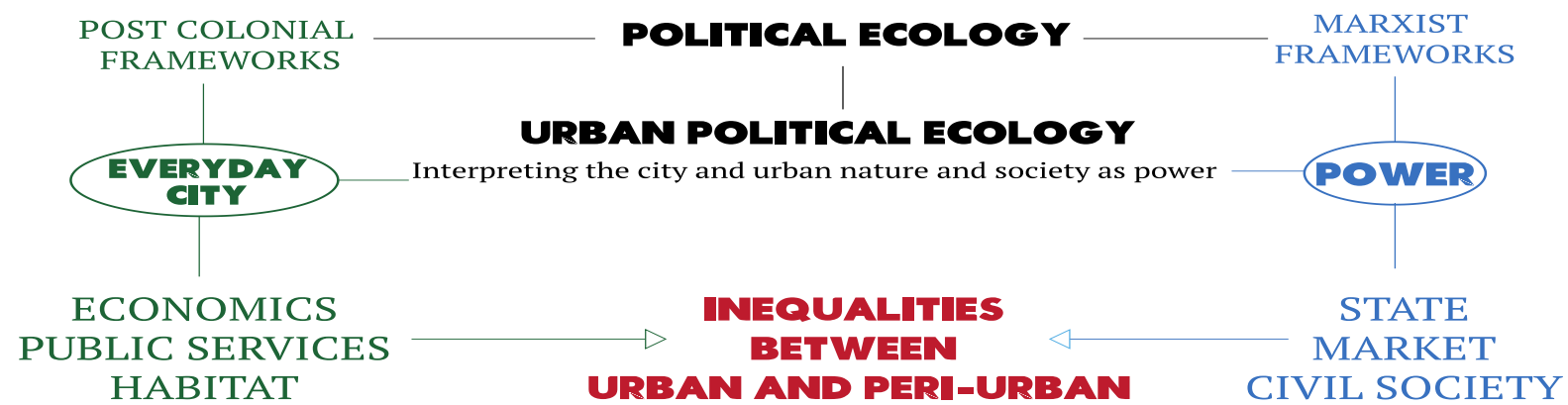

Figure 1. Concept of urban political ecology framework for analysing and explaining inequalities in the peri-urban area

Source: Authors adapted 


\section{Inequalities between peri-urban and urban areas in urbanization process of Ho Chi Minh City}

\subsection{Inequality in economic aspects}

After DoiMoi period, Vietnam has experienced continuously high economic growth. As an economic center of Vietnam, Ho Chi Minh City accounts for a large proportion of the economic growth of Vietnam. However, this transition period and the opening up of the economy have seen a widening gap between the rich and the poor as well as gaps among urban, peri-urban and rural areas. Unequal issues have also emerged on the peri-urban land ownership as a result of the growing demand for land for the urbanization process. With the rapid economic growth in the urbanization process comes an increase in income inequality in Vietnam. According to research conducted by Oxfam (2017), Vietnam's richest citizen can earn an-hour income roughly 5000 times higher than the spending by the poorest Vietnamese in a day. In $\mathrm{HCMC}$, the income gap between the rich and the poor continues to increase at 6.5, 6.6 and 7.37 times in 2012, 2014 and 2015, respectively (GSO, 2015).

\section{Table 1}

GINI Index of Ho Chi Minh City

\begin{tabular}{|l|c|c|c|c|c|c|c|}
\hline & $\mathbf{2 0 0 2}$ & $\mathbf{2 0 0 4}$ & $\mathbf{2 0 0 6}$ & $\mathbf{2 0 0 8}$ & $\mathbf{2 0 0 9}$ & $\mathbf{2 0 1 0}$ & $\mathbf{2 0 1 6}$ \\
\hline HCM City & 0.360 & 0.382 & 0.376 & 0,338 & 0,372 & 0,4 & 0.4 \\
\hline
\end{tabular}

Source: Adapted from GSO of HCMC

The income gap and the rich and poor gap are also estimated based on the Gini coefficient. The Gini coefficient values are from 0 (perfectly equal) to 1 (totally unequal). The Gini Index of Ho Chi Minh city was relatively stable at around 0.36-0.38 during the periods of 2002-2009 but increased to 0.4 in 2016 (Table 1).

\section{Table 2}

The monthly average income per capita at current prices by the residence and by income quintiles

Unit: Thousand dongs

\begin{tabular}{|c|c|c|c|c|c|c|}
\hline & $\mathbf{2 0 0 4}$ & $\mathbf{2 0 0 6}$ & $\mathbf{2 0 0 8}$ & $\mathbf{2 0 1 0}$ & $\mathbf{2 0 1 2}$ & $\mathbf{2 0 1 4}$ \\
\hline Whole city & $\mathbf{1 1 6 4 . 8}$ & $\mathbf{1 4 8 0 . 0}$ & $\mathbf{2 1 9 2 . 0}$ & $\mathbf{2 7 3 7 . 0}$ & $\mathbf{3 6 5 2 . 7}$ & $\mathbf{4 8 3 9 . 7}$ \\
\hline Urban & 1266.9 & 1564.0 & 2359.0 & 2899.8 & 3807.5 & 5118.4 \\
\hline Peri-urban & 726.0 & 939.0 & 1308.0 & 1931.3 & 2925.1 & 3578.4 \\
\hline
\end{tabular}

Source: GSO of Ho Chi Minh City (2015)

Ho Chi Minh citizens are reported an average per capita income of VND4.83 a month. Table 2 shows big differences in average income between people living the urban and peri- 
urban. On average, monthly income per capita in the peri-urban was VND3.5 million, equal to $68 \%$ of urban average income. The per capita income ratio between urban and suburban areas fell slightly from 1.74 in 2004 to 1.43 in 2014. This indicates that the urbanization process has partially helped reduced income inequality between the two areas. Yet, there are still some inequalities. Spending on education in the peri-urban is lower than that in the urban due to lower-income. Average monthly spending on education for peri-urban citizens is VND24,785 and for urban ones is VND62,535 (T. H. Nguyen, 2014). Low education achievement not only affects income but also affects decisions in education, childbirth, child-rearing and other issues for both present and future generations.

\section{Inequality in Land ownership}

As a result of these pressures and rapid socio-economic change in the urbanization process, land resource in HCMC is becoming scarce in the midst of a rapid expansion of industrial zones, planning projects, housing, and infrastructure. In nearly a decade, the area of land used for urbanization projects of HCMC doubled and tended to expand (Fig 2). This leads to a dramatic change in the land use of the suburban area. Moreover, this area also becomes more complex and conflicts over land rights are increasing, especially in the context of the allpeople ownership of land and state management of land in Vietnam (Downes et al., 2016).

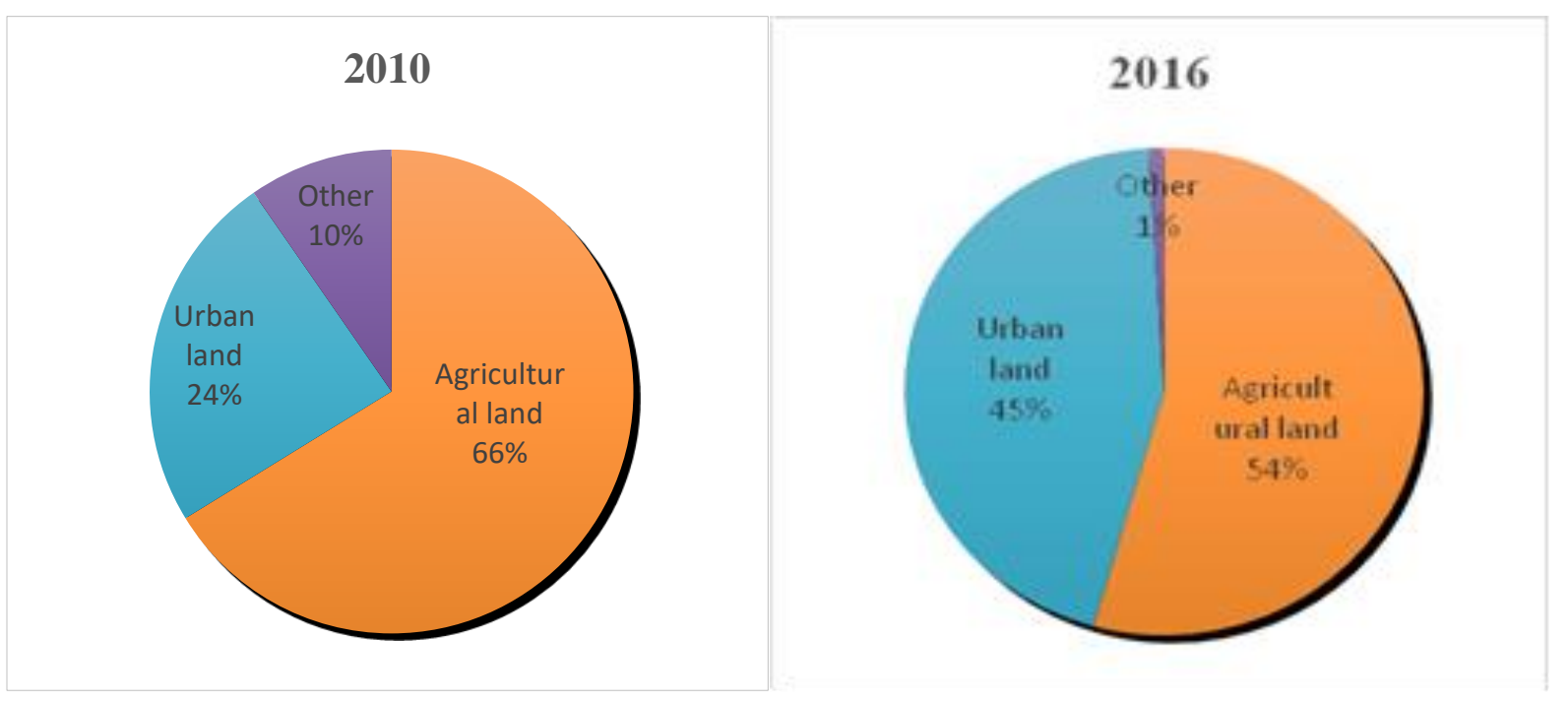

Figure 2. Land-use change in HCMC between 2010 and 2016

Source: Adapted from the General land survey over the years

Accordingly, the inequity in ensuring that land rights, distribution and redistribution of benefits from land in the peri-urban become a controversial issue (Hoa, 2012). Compared to the urban area, there are two main issues about inequalities in the peri-urban.

First, the fluctuation of land ownership in the peri-urban is larger and more complex than that of the urban area. Because of potential land resources and strong land demand in suburban areas, waves in real estate investment have affected people's land ownership in the peri-urban. In contrast, the sector tends to be saturated in the central city (see Table 3). However, the surplus of land due to the planning and investment of infrastructure of the state 
mainly falls into individual investors' pockets. In addition, low land taxes and large revenue losses in the tax collection process exacerbate the inequality. Those who have access to land and real estate increasingly gain profits without contributing to the state while low-income people cannot own land and houses (Hoa, 2012). Accumulation and dispossession of land lead to land speculation, and thus, to economic inequality. This remarkably increases the gap between the rich and the poor. Consequently, the poor cannot afford to buy a piece of land or a house because of the extravagant prices. Therefore, they remain at the bottom of the economic ladder and stay out of the ownership possibility (Harms, 2016).

\section{Table 3}

Number of dossiers certifying land use rights, and ownership of houses attached to the land of HCMC in 2017

\begin{tabular}{|l|c|c|}
\hline & Urban Area & Peri-urban Area \\
\hline First time dossier & 4,800 & 19,200 \\
\hline Dossier changes & 100,687 & 234,939 \\
\hline
\end{tabular}

Source: Report of HCMC Department of Natural Resources and Environment (2017)

Second, the state intervention in land resources is more detrimental to people in the periurban than those in the urban. This is shown by the number of high-density planning projects in the peri-urban. Nearly half of them have delayed projects in which the livelihood of residents is negatively impacted when land-use rights are restricted.

\section{Table 4}

Number of planning projects of HCMC by 2017

\begin{tabular}{|l|c|c|}
\hline & Urban Area & Peri-urban Area \\
\hline Planning projects licensed & 353 & 1.056 \\
\hline Planning projects are slow progress & 114 & 456 \\
\hline
\end{tabular}

Source: Report of HCMC Department of Natural Resources and Environment (2017)

Furthermore, the clearance compensation price for these planning projects has been under a high disparity between the urban and peri-urban areas. In addition, the compensation policy and accessibility are not really satisfactory, do not represent the rights of locals and create high corruption risk and unfair compensation (Hirsch, Mellac, \& Scurrah, 2015). Most compensation projects do not take into account the locals' long-term livelihood. These lead to social discontent and unrest in peri-urban areas such as District 2, 9, 12, Thu Duc, Binh Tan, Binh Chanh and Hoc Mon where the urbanized and industrialized rate are high (VnExpress, 2012).

\subsection{Inequality in accessing public services}

The rate of urbanization in HCMC's suburban area is faster than its rate of infrastructure readiness and growth. The expansion and investment of the city in public services are unequal 
between its peri-urban and urban areas. These make it more difficult for suburban people to access basic education, healthcare and public utilities. This will be specified in more details as follows:

\subsubsection{Inequality in educational opportunities}

In the United Nations Convention on the Rights of the Children (2000) and Children Law of Vietnam National Assembly (2016), equal educational opportunities for all children were clearly asserted. However, education opportunities for students in HCMC's peri-urban area are more limited than those in urban areas in terms of accessibility and quality. For education accessibility, suburban students have fewer education chances than urban ones as the rate of school dropout in the suburban is higher than in the urban (see Table 5). Furthermore, the education quality in the peri-urban is worse than the urban. Overcrowded classes and poor teaching quality of non-public schools in the peri-urban area add to the decrease of quality. Besides, most of the city's talented and gifted programs are designated and adopted by its urban schools.

\section{Accessibility}

According to the law, most children at school ages (up to 18) have the right to join public schools. This practice is compulsory for every child and family. However, there are still a small number of children unable to access public schools as their parents are migrants and do not have a household registration. These children are mostly peri-urban dwellers. As a result, the rate of suburban school dropouts is higher than that of the urban. Recently, the rate of highschool dropouts has declined compared to the early 2000s. High school dropout students are more frequent in the peri-urban area than in the urban.

\section{Table 5}

School dropping rate of Ho Chi Minh City

\begin{tabular}{|l|c|c|}
\hline & Stay rate & School dropping rate \\
\hline Urban districts & 96.8 & 3.2 \\
\hline Peri-urban districts & 90 & 10 \\
\hline
\end{tabular}

Source: Adapted from the GSO of Ho Chi Minh City (2015)

Participation and completion of children in the learning process at schools go hand in hand with macro issues such as economic difficulties and household registration procedures. Extra learning pressure often combines one or two factors and relates to economic reasons. In Ho Chi Minh City, the rapid population growth poses many challenges for city education in ensuring fair education for all children, especially for migrant children. The fact that some of the migrants including seasonal migrants do not have adequate shelters also affects the timely census of the population to ensure the rights to education. This cannot ensure equal educational opportunity for all children, especially for those in the peri-urban. 


\section{Education quality}

According to General Statistics of Vietnam, the 2016 HCMC educational budget for the peri-urban is less than that for the urban with $6.1 \%$ for the former and $10.8 \%$ for the latter (GSO, 2017). Because of fewer funds for infrastructure, fewer public schools are constructed in the peri-urban to meet the increasing demand. As a result, students have no choices other than learning in overcrowded classes with weak non-public school quality adding to the poor quality of the peri-urban school system. Table 6 shows that there are only 21 students per urban preschool class while this number is 44 in peri-urban one. The number of teachers per primary class in these two areas is 27 and 31 respectively.

\section{Table 6}

Average number of pupils per class and average number of pupils per teacher in urban and periurban areas in 2014

\begin{tabular}{|l|l|c|c|c|c|}
\hline & & Preschool & Primary & Secondary & High school \\
\hline \multirow{2}{*}{$\begin{array}{l}\text { Average number of } \\
\text { students per class }\end{array}$} & Urban & $\mathbf{2 1}$ & 39 & 41 & 38 \\
\cline { 2 - 6 } & Peri-urban & $\mathbf{4 4}$ & 41 & 42 & 39 \\
\hline \multirow{2}{*}{$\begin{array}{l}\text { Average number of } \\
\text { student per teacher }\end{array}$} & Urban & 15 & $\mathbf{2 7}$ & 21 & 15 \\
\cline { 2 - 6 } & Peri-urban & 17 & $\mathbf{3 1}$ & 22 & 16 \\
\hline
\end{tabular}

Source: Adapted from GSO of Ho Chi Minh City (2015)

Therefore, the above findings assert that education quality provided for students has been negatively influenced when the class is oversized and the teacher cannot assure the standard for each student.

As public pre-school facilities are limited with the system capacity in the peri-urban where there is a high concentration of migrants. Parents who are working in industrial parks and export processing zones have to send their under-36-month children to private and familybased childcare services. Proactively, the non-public pre-school sector has predominated over the public sector, accounted for $58 \%$ of pre-school children in the peri-urban currently attending non-public education facilities while this is only 39\% in the urban during 2015-2016. It is noteworthy that the number of the non-public pre-school students, main kindergarteners in four peri-urban districts (district 12, Binh Tan, Thu Duc and Binh Chanh) accounted for more than $70 \%$ of the preschoolers while the number of public preschoolers in four urban districts (district $1,4,5$ and 11) only accounted around $25 \%$. 


\section{Table 7}

Percentage of pre-school children attending non-public education facilities in urban and periurban districts, Ho Chi Minh City (2015-2016 school year)

\begin{tabular}{|l|l|l|}
\hline \multirow{4}{*}{ Urban districts } & District 1 & $24,4 \%$ \\
\cline { 2 - 3 } & District 4 & $25,4 \%$ \\
\cline { 2 - 3 } & District 5 & $21,9 \%$ \\
\cline { 2 - 3 } & District 11 & $33,5 \%$ \\
\hline \multirow{3}{*}{ Peri-urban districts } & District 12 & $75,3 \%$ \\
\cline { 2 - 3 } & Binh Tan & $73,6 \%$ \\
\cline { 2 - 3 } & Thu Duc & $72,1 \%$ \\
\cline { 2 - 3 } & Binh Chanh & $63,1 \%$ \\
\hline
\end{tabular}

Source: GSO of Ho Chi Minh City (2015)

Controversially, non-public pre-school facilities are often of poorer quality and children have risks of being badly treated or beaten. These schools do not meet quality requirements in comparison with the public sector in terms of facilities and manner and education methodologies.

To sum up, the rapid population growth along with the urbanization process in the periurban exceeds the capacity of the education infrastructure system due to the lack of government expenditure. Overcrowded classes and poor quality of the non-public schools in the peri-urban worsen education quality there. Furthermore, the higher rate of school dropout students in the peri-urban is obstructing the children's accessibility to further education.

\subsubsection{Health care}

The rapid urbanization process in Ho Chi Minh City accelerates differences in quantity and quality of health services and accessibility of people living in urban and peri-urban. Areas. Although urbanization brings many opportunities including potential access to better healthcare but proposes many challenges when the gap between the rich and the poor is more and more widening and leading to inequality, especially in public health care.

\section{Quality of hospital facilities and services}

Unlike the center urban, the peri-urban lacks hospitals, regional polyclinics, preventive medicine centers and medical service units at communal and precinct levels. The shortage of human resources in public healthcare in Vietnam in general and HCMC, in particular, is severe because doctors are hard to come by in rural areas since they tend to practice in the most advanced urban locales.

Some tertiary hospitals such as Cho Ray, Hung Vuong, Gia Dinh and Hospital of the University of Medicine located in districts 1, 3, 5 and 10 (center urban) are considered good and sufficient to provide people with their out-patient and in-patient services. These hospitals have been overloaded with visits of the peri-urban dwellers and other provincial residents since 
the majority of hospitals located in the peri-urban areas are lacking experienced and highquality doctors, physicians and nurses. Poor public investment in equipment and facilities in the peri-urban consequently impedes the quality of physicians' practice. Therefore, the residents and dwellers of these areas are suffering from the outdated medical equipment, combined with the limited access to the latest drugs in Vietnamese public hospitals (specifically in small hospitals).

The ratio of the proper diagnostic and accurate treatment from the peri-urban doctors and physicians is about $50 \%$ and the ratio of the proper diagnostic but wrong treatment consultancy is about $70 \%$. The reality is that most of the patients exit their primary care providers or hospitals at the commune level to go for the secondary or tertiary ones since they do not trust in the quality of doctors and physicians at small public hospitals. The functionality of the preventive medicine centers at commune levels is not linked to care, without any wellgrounded and continuous solutions (BaoMoi Newspaper, 2017).

\section{Access to medical care}

Health inequality in HCMC especially in the peri-urban areas with mainly poor migrants and working-class inhabitants has recently caught the attention of the public because their access to health services and insurance is limited due to their residency status as insurance holders. Attracted by the quick urbanization process, migrants move to HCMC and live mostly in new industrial zones, factories or shift-houses located in the peri-urban. The residential registration system is a barrier for migrants in accessing public healthcare services HCMC's trick household and residency regulations make it impossible for migrants to approach public healthcare services although $80 \%$ of the city's citizens have obtained insurance and coverage. HCMC's health financing depends on private expenditure by households, especially out-ofpocket payments. This out-of-pocket value increased from 43.5 percent in 2012 to 48 percent in 2013. This situation deepens the gap and inequality between people living in rural and periurban areas and city people because poor people have to pay more for health expenditures (Oxfam, 2017). As a result, poor people become poorer compared to the rich and urban residents. This continues to be a pervasive problem.

\subsubsection{Access to safe water and electricity}

Compared to urban districts, access to public utilities, especially water and electricity is harder for people living in the peri-urban. Many households in the peri-urban cannot use clean water and electricity due to weak infrastructure systems and remote location. According to a 2014 Vietnam Housing and Living Standards Survey, 23.5\% of households in Ho Chi Minh City are too poor and live without clean and safe water; $9 \%$ without waste collection services and around 1\% without access to the national electric power grid. These people live in periurban areas such as $\mathrm{Cu}$ Chi, Hoc Mon, District 12, Thu Duc and Can Gio.

By the end of 2016, Saigon Water Corporation (Sawaco), a state-owned company, announced that they successfully supplied clean water to all households in HCMC including all the peri-urban and rural districts. However, the water supply is not stable in some peri-urban areas. In some areas of Hoc Mon, Binh Chanh and District 12, Sawaco still has not finished installing water pipes to directly supply clean water to each household and deliver through water tanks with a common meter instead. Therefore, around 12,000 households have to walk to the commune centers to buy and carry water home. Moreover, due to a high net migration rate, Sawaco could not manage to quickly supply water to the new migrant households. The company 
is making efforts to install stable water supply systems and meters for locals in these districts (Sawaco, 2017). This inconvenience and the expensive access to clean water make most suburban people have no choice but to use water from untreated sources such as well water and polluted water from rivers or canals. A water quality test on 1,400 samples from households in 7 peri-urban districts (District 12, Thu Duc, Binh Tan, Binh Chanh, Hoc Mon, $\mathrm{Cu}$ Chi and Nha Be) showed that 97 percent of these water do not meet the water quality standard and contain various bacteria and harmful chemicals such as arsenic and ammonium (Giadinhnet, 2015).

As for electricity, migrants and non-residents have to unreasonably pay at a higher rate than permanent residents because they do not have household registration. This situation digs out the inequality between people in the two areas. They even cannot turn on ready-installed air-conditioners in hot weather du tot the high costs.

\subsection{Inequality benefits in the quality of the natural and social environment}

HCMC's urbanization expansion creates some adverse impacts on the quality of natural and social environment especially to the peri-urban districts as these areas are most vulnerable to environmental pollution and social problems. Otherwise, inadequate development processes, unequal distribution of services and investment, the ignorance of environmental protection and cultural preserve negatively impact the quality of livelihood in the peri-urban. Those facts show the inequality of the quality of natural and social environment between residents in the periurban and urban because of the negatively changing natural landscape, environment pollution and the negative changing of culture and living of the peri-urban (Habitat for humanity Vietnam, 2008; Hoang, Truong, \& Dinh, 2013; V. T. Le, 2007; V. N. Le, 2007; Putta \& Ravadi, 2014; Truong, 2013).

\section{Table 8}

The impact of urbanization leads to the inequality in the quality of natural and social environment between residents in peri-urban and urban in Ho Chi Minh City

\begin{tabular}{|l|l|l|l|l|}
\hline $\begin{array}{c}\text { Spatial } \\
\text { urbanization }\end{array}$ & \multicolumn{1}{|c|}{$\begin{array}{c}\text { General } \\
\text { characteristic }\end{array}$} & $\begin{array}{c}\text { Changing } \\
\text { natural } \\
\text { landscape }\end{array}$ & $\begin{array}{c}\text { Environment } \\
\text { al Pollution }\end{array}$ & $\begin{array}{c}\text { Changing of } \\
\text { cultural and living } \\
\text { environment }\end{array}$ \\
\hline Urban & $\begin{array}{l}\text { - The old inner } \\
\text { centre } \\
\text { - High level of } \\
\text { development } \\
\text { - High level of } \\
\text { urbanization }\end{array}$ & $\begin{array}{l}\text { Changing natural } \\
\text { landscape is few }\end{array}$ & Serious & $\begin{array}{l}\text { Partly reserve and } \\
\text { stable }\end{array}$ \\
\hline
\end{tabular}




\begin{tabular}{|c|c|c|c|c|}
\hline $\begin{array}{c}\text { Spatial } \\
\text { urbanization }\end{array}$ & $\begin{array}{c}\text { General } \\
\text { characteristic }\end{array}$ & $\begin{array}{c}\text { Changing } \\
\text { natural } \\
\text { landscape }\end{array}$ & $\begin{array}{c}\text { Environment } \\
\text { al Pollution }\end{array}$ & $\begin{array}{c}\text { Changing of } \\
\text { cultural and living } \\
\text { environment }\end{array}$ \\
\hline Peri-Urban & $\begin{array}{l}\text { - Areas } \\
\text { immediately on } \\
\text { the periphery of } \\
\text { urban areas } \\
\text { - A mix of } \\
\text { urban, industrial } \\
\text { and rural land } \\
\text { use } \\
\text { - Undergoing } \\
\text { rapid urbanization }\end{array}$ & $\begin{array}{l}\text { Natural landscape } \\
\text { is significantly } \\
\text { changed and more } \\
\text { vulnerable in the } \\
\text { area surrounding } \\
\text { the industry zones. } \\
\text { As result, Peri- } \\
\text { urban suffers from } \\
\text { environmental } \\
\text { hazards }\end{array}$ & More serious & $\begin{array}{l}\text { Historical relics and the } \\
\text { community was totally } \\
\text { destroyed, and living } \\
\text { environment is changec } \\
\text { toward negative (less } \\
\text { safe) }\end{array}$ \\
\hline
\end{tabular}

Source: Authors adapted

\section{The changing natural landscape and environmental pollution}

During the rapid urbanization process, HCMC's peri-urban districts have witnessed the great environmental transformation in which land use for agriculture is converted to urban resettlements and industrial zones. Approximately 330,000 hectares of agricultural land in the peri-urban were changed into urban in the 200-2010 periods (Truong, Truong, \& Son, 2017). Natural landscapes were replaced by new buildings, houses and industrial zones. Trương's survey shows that $83 \%$ of the farmers said that the surrounding landscape has changed a lot and they feel regretted the loss of green and peaceful rural landscapes (Truong, 2013). These natural landscape changes lead to the shrinkage of water surfaces and the disappearance of natural water reservoirs. Many ponds, lakes, canals and lands are leveled off for urban construction and these construction sites take up spaces previously used for floodwater drainage. Residents in Thu Duc and Nha Be district often experience severe floods during high flood-tide from June to November every year while people in urban districts only suffer from flood water after heavy rains (Ministry of Natural Resources and Environment, 2016).

The peri-urban also faces numerous environmental problems, especially water resource deterioration. Most of HCMC's industrial zones and parks often locate in the peri-urban. 1.235 factories and small enterprises have been moved out of the city center and resettled in the periurban (mostly in district 7, 9, 12, Binh Tan and Thu Duc district) in the period 2010-2018 (Ministry of Natural Resources and Environment, 2016). Although all registered enterprises are obliged to treat their wastewater, the installation of wastewater treatment facilities is not adequately enforced. Many industrial zones have delayed the construction of wastewater treatment systems (Nguyen, 2010).

\section{Change of cultural and living environment}

The cultural and living environment has been changed negatively in the peri-urban due to urbanization while residents in the urban enjoy their stable communities, cultural activities and safe living environment. In the peri-urban, many historical relics like old pagodas, churches 
and temples were destroyed to build new urban and industrial zones. As residents sell land to earn more money and they have to move to other places to relocate their communities loss. The households choose a new urban lifestyle so the social ties tend to loosen and rural culture gradually disappears (Truong, 2013).

Furthermore, residents in the peri-urban feel unsafe due to the increase of bad entertainment and social evils. Newly-urbanized areas fill with coffee shops, karaoke shops, business and modern houses, but residents also admitted that their life is becoming more "complicated". They said the area has more social evils (drug, thefts, gamble, titty bar or "beer ôm") as the urban develop. Half of the arrested criminals were born in the peri-urban. The mixing of rural and urban seems frightening indeed (Harms, 2011; Truong, 2013).

Although urbanization in the peri-urban aims to improve the living conditions of people, it destroys the ecological system, communities and cultural activities. This shows the unequal quality of living between residents in the peri-urban and urban. These are results of inadequate development processes, unequal distribution of services and investments and the ignorance of environmental protection from the state; the poor consciousness of residents; the weak civil society organizations and lack of effective environmental services. These factors will be analyzed below.

\section{Discussion}

\subsection{Inequalities between urban and peri-urban as the inevitability of urban metabolism}

The urbanization in HCMC is rapid, complex and has a great impact on nature and society. This metabolism causes polarization of many HCMC areas creating the central urban, peri-urban and rural areas. In which, the structure of suburban society and the economy suffered the most by "new and more complex relationship between society and nature are created" (Keil, 2003 , p. 729) during the urbanization process. Obviously, the inequalities in this area are more serious and popular than in the urban.

The inequalities can be observed through the "everyday practices". While "everyday practices are stable" in the central urban, it fluctuates continuously in the peri-urban as urban metabolism. First, industrialization and migration blooming in this area have led to changing jobs, habitat, and income of local people. Second, the allocation of resources is under restricted conditions because HCMC is under the pressure of contributing and sharing resources with the entire country. Therefore, natural and social resources such as electricity, water and finance tend to be prioritized for the development of public services and improve the living conditions of urban people rather than rural ones.

Although inequality is inevitable in urban metabolism, the HCMC government can create favorable conditions to mitigate the consequences of urbanization. Yet, the state chose economic development as a priority on their agenda so the status of inequalities between the peri-urban and center urban in HCMC are still strong, which is the downside of urbanization and is unlikely to be avoided. 


\subsection{Powers of creating or controlling inequalities between urban and peri-urban}

\subsubsection{State power}

According to many scholars, interventions of the state usually affect the development process (Behera, 2006; Casares, Tortella, \& el-Khazen, 2000; Kramer \& Flanagan, 2012). In the urban development of HCMC, there are also two scenarios for state intervention in the urban metabolism process. The successful interventions will help solve the inequities between the urban and the peri-urban. Conversely, intervention failure can cause inequalities and even make them more serious. According to the above analysis, the state intervention, in this case, is the second scenario. There are many causes of this failure.

Firstly, the peri-urban lacks a comprehensive, robust and rational institution to control the influence of power groups on natural resources, especially on the land resource (May, 2015). This leads to inequalities due to speculation and corruption. Moreover, some policies of the state are unreasonable, unrealistic and lack social consensus. In addition, some policies are overlapping, tenacious, and ineffective (Lucius, 2009). These policies led to interactions between political and economic institutions and affect the way humans interact with their environment. In this case, they prevent people from interacting with their urban environment and force them to interact with the rural environment in certain ways.

Secondly, there are many limitations in decentralization and autonomy that are considered as the barriers to equality between the urban and peri-urban although these areas contribute a large portion to the national budget (C. T. Nguyen, 2013). As mentioned above, healthcare and education systems in HCMC clearly demonstrate an ineffective intervention of state governance, leading to an imbalance in quality and quantity of public services between the urban and peri-urban. Lack of resources for investment in infrastructure to improve the suburban environment is also one of the consequences of inefficient allocation of resources from the government. For the environment, a suburban environment with rapid urbanization speed is likely to be more vulnerable than an urban environment. However, the urban is often given more environmental investment priority over the suburban. More seriously, the government apparatus in the peri-urban is the same as the center and rural areas while this area is facing more problems (V. N. Le, 2007). Issues such as pollution, illegal construction and social evils are not effectively controlled because of low institutional capacity, weak coordination and cooperation, limited independence, corruption, the over-centralization of environmental responsibilities in weak national environmental bureaucracies.

Thirdly, there is still a state monopoly in public services such as electricity, water, healthcare, and education while the quantity and quality of their services have not met the demand of urban development (X. Q. Dinh, 1999; T. M. Dinh, 2014). In addition, the state does not guarantee fair competition between state and private companies to improve the quality of supply (D. D. Le, 2013). The privatization process of state-owned companies is slow and limited.

\subsubsection{Market power}

The market is one of the strongest influences on the urban metabolism process of HCMC (Kontgis et al., 2014). The increase in production and consumer demand has triggered market factors that focus on production and services. This process changes the labor market; many 
people from the agricultural sector are forced to become workers, small businesses or unemployed. These impacts change livelihoods and income.

Market participation in suburban public services from many sectors especially private sector has improved but is still constrained by the monopoly and affiliation of state-owned companies (T. M. Dinh, 2014, D. D. Le, 2013). Namely, HCMC health system lacks privatization because of unattractive policies such as tax, patient fees and quality and facility guidelines as shown above. And low demand in the healthcare of the peri-urban low-income households does not create the potential market for private investors. They will not try to exploit the investment opportunities in the peri-urban if the HCMC healthcare policymakers do not try to constitutionalize privatization and public-private partnership for healthcare policy. Similarly, education costs are so expensive for many peri-urban families and thus, become challenges of privatizing the education system.

\subsubsection{Civil society power}

The power of civil society organizations in Vietnam is currently weak because the establishment of a civil society organization requires many strict conditions by the law. Therefore, the formal power of the people is mainly expressed through state organizations (Kerkvliet, 1995; P. T. Le, 2013; Wischermann, Nguyen, Bui, Dang, \& Nguyen, 2015). Land compensation and reallocation between the project developers and displaced residents in the urbanization process are unreasonable due to inequality in power distribution and the week voice of civil society. An urbanization process without "participation" and "empowerment" can make policies reflect only the government's wishes and ignore the experience and culture of peri-urban people.

Furthermore, NGOs face many challenges due to lack of support and bureaucracy of local authorities (Hannah, 2007) as in the fields of health care and education. NGOs play an important role in reducing health and education inequality in developing countries like Viet Nam. However, the peri-urban area does not get enough help and funds from NGOs as expected because it is quite difficult for NGOs to get the permit from the city to local authorities for this.

\section{Conclusion}

Understanding UPE can provide useful references for analyzing and comparing the inequality status between the urban and peri-urban in HCMC based on their "everyday practices" in economics, public services, and the environment. This study showed many inequalities between the two areas during the inevitable urban metabolism. Furthermore, the urban political ecology approach can point out the reasons of these inequalities based on the power interaction between the state, civil society and market. This study found that the centralization of state power, lack of control over the relationship between public-private group interest, lack of participation of the civil actor in the decision-making process have led to the failure of the intervention of urban metabolism, causing inequalities between the urban and peri-urban of HCMC. Apart from analyzing and interpreting the situation, UPE also suggests some solutions to eradicate the inequities between the urban and peri-urban. To adjust the power imbalance in the urban metabolism, the urban political ecologists support the views that urban governance should shift from a state-centric management model to a governance model involving non-state actors such as market actors and civil society. 
The implications for further research are on innovative solutions for the governance model of the city to solve the inequalities between the urban and rural-urban, including the development of a good institutional framework for urban governance; renovation of public services in the direction of effective urban governance; and more transparency and accountability focus.

\section{References}

Asian Development Bank (ADB). (2014). Urban poverty in Asia. Retrieved January 21, 2018, from https://www.adb.org/sites/default/files/publication/59778/urban-poverty-asia.pdf

BaoMoi Newspaper. (2017). Alert about the knowledge and skills of doctors at the health facilities. Retrieved June 22, 2018, from https://baomoi.com/bao-dong-do-ve-kien-thucva-ky-nang-cua-bac si-y-te-co-so/c/22125720.epi

BaoMoi Newspaper. (2017). Ho Chi Minh City: Most of denunciations are about land use right. Retrieved June 4, 2018, from https://baomoi.com/tp-ho-chi-minh-da-so-cac-vu-khieunai-lien-quan-den-linh-vuc-dat dai/c/23784988.epi

Behera, M. C. (2006). Globalizing rural development: Competing paradigms and emerging realities. New Delhi, India: SAGE Publications India.

Blaikie, P., \& Brookfield, H. (1987). Defining and debating the problem. In P. Bryant, G. Lynne, H. Brookfield, M. Sesay, J. Richards, R. Chambers, ...Roberts, N. Land degradation and society/Piers Blaikie and Harold Brookfield with contributions.

Casares, G. T., Tortella, G., \& el-Khazen, F. (2000). The development of modern Spain: An economic history of the nineteenth and twentieth centuries, 61(1), 210-211. Cambridge, UK: Harvard University Press.

CBRE Vietnam. (2017). CBRE Vietnam market view Q4 2017. Retrieved June 4, 2018, from http://www.cbrevietnam.com/?useful=cbre-vietnam-marketview-q4-2017

Dautu Online. (2018). Ha Noi, Ho Chi Minh City, Da Nang received the highest numbers of citizens' arrivals for denunciations and petitions on land use right issue. Retrieved June 4, 2018, from http://baodautu.vn/ha-noi-tphom-da-nang-dan-dau-luong-don-thu-khieunai-to-cao-ve-dat-dai-d82738.html

Dinh, T. M. (2014). Improve market institutions for public goods and services. In Macroeconomic report 2014: Economic institutional reform - Key to restructuring. Hanoi, Vietnam: Tri Thuc Publication.

Dinh, X. Q. (1999). The state and the social sector in Vietnam: Reforms and challenges for Vietnam. ASEAN Economic Bulletin, 16(3), 373-393.

DoanhNhanSaiGon Online. (2016). Ho Chi Minh City and pressure of the 13 million population on urban infrastructure. Retrieved June 21, 2018, from https://doanhnhansaigon.vn/batdong-san/tp-hcm-va-suc ep-ha-tang-tu-do-thi-13-trieu-dan-1073255.html

Downes, N. K., Storch, H., Schmidt, M., Nguyen, V. T. C., Le, D. C., Tran, N. T., \& Le, H, T. (2016). Understanding Ho Chi Minh City's urban structures for urban land-use monitoring and risk-adapted land-use planning. In Sustainable Ho Chi Minh City: 
Climate policies for emerging mega cities (pp. 89-116). New York, NY: Springer, Cham.

Edensor, T., \& Jayne, M. (2012). Urban political ecology in the global south: Everyday environmental struggles of home in Managua, Nicaragua. In L. Shillington (Ed.), Urban theory beyond the West (pp. 295-310). London, UK: Routledge.

ForbersPharma \& Healthcare. (2014). Healthcare in Viet Nam-Part I. Retrieved June 22, 2018, from https://www.forbes.com/sites/benjaminshobert/2014/07/31/healthcare-in-vietnampart-1/\#77b6c57c44fdon June 22, 2018.

Foucault, M. (2007). Security, territory, population: Lectures at the Collège de France, 1977, 78. New York, NY: Springer.

General Statistics Office of Vietnam (GSO). (2015). Statistical yearbook 2015. Hanoi, Vietnam: Vietnam Statistics Office Publisher.

General Statistics Office of Vietnam (GSO). (2017). Statistical yearbook 2017. Retrieved June 28, 2018, from https://www.gso.gov.vn/Default.aspx?tabid=217

Giadinhnet. (2015). Ho Chi Minh City peri-urban citizens: Using water from drilled well in anxiety. Retrieved June 4, 2018, from http://giadinh.net.vn/song-khoe/cu-dan-ngoaithanh-tphcm-vua-dung nuoc-gieng-khoan-vua-lo-ngay-ngay-20150708135610157.html

Habitat for humanity Vietnam. (2008). Mapping urban poverty in Ho Chi Minh City. Retrieved June 10, 2018, from https://docplayer.net/29477345-Mapping-urban-poverty-in-ho-chiminh-city.html

Hannah, J. (2007). Local non-government organization in Vietnam: Development, civil society and state-society relations (Doctoral dissertation, University of Washington, Seattle, USA). Retrieved May 10, 2017, from http://staff.washington.edu/jhannah/dissertation/Hannah\%20-$\% 20$ Research\%20proposal.pdf

Harms, E. (2011). Saigon edge on the margins of Ho Chi Minh City. Minneapolis, MN: University of Minnesota.

Harms, E. (2016). Luxury and rubble: Civility and dispossession in the new Saigon. Berkeley, CA: University of California Press.

Harvey, D. (1989). From managerialism to entrepreneurialism: The transformation in urban governance in late capitalism. Geografiska Annaler: Series B, Human Geography, 71(1), 3-17.

Harvey, D. (1997). Contested cities: Social process and spatial form. In N. Jewson \& MacGregor (Eds.), The city reader.

HCMC Department of Natural Resources and Environment. (2017). Certifying land use rights, and ownership of houses attached to land of HCMC. Retrieved June 21, 2018, from HCMC Department of Natural Resources and Environment.

Hirsch, P., Mellac, M., \& Scurrah, N. (2015). The political economy of land governance in Vietnam. Retrieved October 20, 2017, from https://halshs.archives-ouvertes.fr/halshs02372282/file/HIRSH\%20SCURRAH\%20MELLAC_2015_Political-Economy-LandGovernance_Vietnam.pdf 
Ho Chi Minh City People's Committee and UNICEF. (2017). Situation analysis of children: In Ho Chi Minh City - Viet Nam 2017. Retrieved October 21, 2017, https://vietnam.un.org/sites/default/files/2019-

08/Final\%20Sitan\%20HCMC\%20Eng_0.pdf

Hoang, T. X., Truong, A. T., \& Dinh, P. T. T. (2013). Urban poverty in Vietnam - A view from complementary assessments. Retrieved June 21, 2017, from http://pubs.iied.org/pdfs/10633IIED.pdf

Keil, R. (2003). Urban political ecology. Urban Geography, 24(8), 723-738.

Kerkvliet, B. J. T. (1995). Rural society and state relations. In B. J. T. Kerkvliet (Ed.), Vietnam's rural transformation.

Kim, A. M. (2011). Talking back: The role of narrative in Vietnam's recent land compensation changes. Urban Studies, 48(3), 493-508.

Kontgis, C., Schneider, A., Fox, J., Saksena, S., Spencer, J. H., \& Castrence, M. (2014). Monitoring peri-urbanization in the greater Ho Chi Minh City metropolitan area. Applied Geography, 53, 377-388.

Kramer, D. C., \& Flanagan, R. M. (2012). Staten island: Conservative bastion in a Liberal City. Lanham, MA: University Press of America.

Latour, B. (2004). Politics of nature. Cambridge, MA: Harvard University Press.

Le, D. D. (2013). Economic institutions and political institutions reform to create the environment competitive environment. Proceedings of The Autumn Economic Forum 2013.

Le, P. T. (2013). Tracing the discourse on civil society in Vietnam - A narrative from within. In G. Waibel, J., Ehlert \& H. Feuer (Eds.), Southeast Asia and the civil society gaze: Scoping a contested concept in Cambodia and Vietnam (pp. 171-186). New York, NY: Routledge.

Le, V. N. (2007). Farmers in suburban Ho Chi Minh City in the process of urbanization. Ho Chi Minh, Vietnam: The Ho Chi Minh City general publishing house.

Le, V. T. (2007). Economic development, urbanization and environmental changes in Ho Chi Minh City, Vietnam: Relations and policies. Paper presented at the PRIPODE workshop on Urban Population, Development and Environment Dynamics in Developing Countries, Nairobi, Kenya.

Lucius, C. (2009). Vietnam's political process: How education shapes political decision making. London, UK: Routledge.

May, K. (2015). Restructuring Vietnam's urban land governance: New state spaces in Ho Chi Minh City (Master's thesis, The University of Guelph, Canada). Retrieved October 10, 2017 ,

from https://atrium.lib.uoguelph.ca/xmlui/bitstream/handle/10214/8657/May_Kristy_201412 _MA.pdf?sequence $=3$ \&isAllowed $=y$ 
Ministry of Natural Resources and Environment. (2016). Environmental report of Vietnam 2016: Urban environment. Hanoi, Vietnam: Viet Nam Natural Resources and Environment Publishing House.

Minot, N., Baulch, B., \& Epprecht, M. (2013). Poverty and inequality in Vietnam: Spatial patterns and geographic determinants. Retrieved June 21, 2018, from http://siteresources.worldbank.org/INTPGI/Resources/3426741092157888460/Minot.PovertyInequalityVietnam.pdf.

Nguyen, C. T. (2013). Municipal government in Vietnam: Case studies of Ho Chi Minh City and $D a$ Nang. Retrieved June 20, 2017, from https://asiafoundation.org/resources/pdfs/MunicipalGovermentVietnamese.pdf

Nguyen, A. H. (2010). Wastewater management and treatment in urban areas in Viet Nam. Paper presented at The 1st WEPA International Workshop, Hanoi, Viet Nam.

Nguyen, T. H. (2014). Some causes of suburban poverty in Ho Chi Minh City. Academic politics region II.

Oxfam. (2017). Even it up: How to tackle inequality in Vietnam. Retrieved June 4, 2018, from https://d1tn3vj7xz9fdh.cloudfront.net/s3fs-public/file_attachments/bp-vietnaminequality-120117-en.pdf

PricewaterhouseCoopers USA (PwC). (2014). Us health industries and global health industries. Retrieved June 22, 2018, from https://www.pwc.com/us/en/healthindustries/health-research-institute.html on.

Putta, V., \& Ravadi, N. (2014). Role of urban planning as a tool to mitigate the environmental repercussions due to Peri-Urbanization. Journal of Civil Engineering and Environmental Technology, 1(3), 96-102.

Roy, A. (2009). Civic governmentality: The politics of inclusion in Beirut and Mumbai. Antipode, 41(1), 159-179.

Sawaco. (2017). Cấp nước bền vũng cho 51.000 hộ dân ngoại thành [Stable safe water supply for 51,000 households in peri-urban areas]. Retrieved June 11, 2018, from http://www.sawaco.com.vn/wps/wcm/ connect/web+content/sawaco/tintucsukien/tintuc/c43f83b4-e2c2-4824-9a9ceafc749320fe

Simone, A. (2004). For the city yet to come: Changing African life in four cities. Durham, NC: Duke University Press.

Stumpf, M. J. (2012). Housing and urbanization: A socio-spatial analysis of resettlement projects in Ho Chi Minh City. Retrieved June 1, 2018, from http://digitalcollections.sit.edu/isp_collection/1284

Swyngedouw, E. (2004). Scaled geographies: Nature, place, and the politics of scale. In Scale and geographic inquiry: Nature, society, and method (pp. 129-153).

Swyngedouw, E., \& Heynen, N. C. (2003). Urban political ecology, justice and the politics of scale. Antipode, 35(5), 898-918. 
The National Assembly. (2016). Children Law. Retrieved June 1, 2018, from http://vbpl.vn/TW/Pages/vbpqen-toanvan.aspx?ItemID=11044

Tran, T. K. X. (2017). Child education in Ho Chi Minh City: The gap of educational access between center and peripheral area. Van Hien University Journal of Science, 5(3).

Truong, T. H. (2013). Rapid rural urbanization in Ho Chi Minh City facing the process of modernization, globalization - A case study of Vinh Loc A, Binh Chanh district, Ho Chi Minh City. Ho Chi Minh, Vietnam: HCMC Institute for Development Studies.

Truong, T. H., Truong, T. T., \& Son, T. T. (2017). Housing and transportation in Vietnam's Ho Chi Minh City. Retrieved June 20, 2017, from https://library.fes.de/pdffiles/bueros/vietnam/13909.pdf

UNDP Vietnam. (2015). Justice Index - Towards a justice system for the people. Retrieved March 22, 2018 , from http://www.vn.undp.org/content/vietnam/en/home/library/democratic_governance/2015 -justice-index.html

United Nations Convention on the Rights of the Children. (2000). The United Nations Convention on the Rights of the Child: Background and Policy Issues. Retrieved March 26, 2018, from https://www.refworld.org/pdfid/4d19fa2327f.pdf

United Nations Industrial Development Organization and Ministry of Planning Investment. (2015). Implementation of eco-industrial park initiatives for sustainable industrial zones in Vietnam. Retrieved March 20, 2018, from http://www.wrforum.org/wpcontent/uploads/2015/10/SS13-Leuenberger.pdf?lang=it

United Nations. (2016). Vietnam at a glance. Retrieved August 20, 2016, from http://www.un.org.vn/en/ about-viet-nam/overview.html

Vietnam Inequality Report. (2005). Assessment and policy choices. Paper presented at the "DFID Drivers of Inequality in Vietnam" Project, Mekong Economics Ltd. Synthesis, Vietnam.

VnExpress. (2012). Many large group denunciations on land use right issues happened in Ho Chi Minh City. Retrieved June 11, 2018, from https://vnexpress.net/tin-tuc/thoi-su/nhieuvu-khieu-nai-dong-nguoi-ve-dat-dai-o-tp-hcm-2239291.html

Wischermann, J., Nguyen, Q. V., Bui, T. C., Dang, T. V. P., \& Nguyen, T. M. C. (2015). Under the state's thumb: Result from an empirical survey of civic organization in Vietnam. German Institute of Global and Area Studies Working Paper, 276, 1-35.

Zimmer, A. (2010). Urban political ecology: Theoretical concepts, challenges, and suggested future directions. Erdkunde, 64(4), 343-354. 